\title{
PENGARUH KUALITAS PELAYANAN, LOKASI DAN WORD OF MOUTH TERHADAP KEPUTUSAN PEMBELIAN PADA ANUGERAH AL-BAGHDADI MEBEL KARAWANG
}

\author{
Robby Fauji \\ Universitas Singaperbangsa Karawang \\ robbyfauji14@gmail.com
}

\begin{abstract}
ABSTRAK
Anugerah Al-baghdadi Mebel merupakan perusahaan mebel yang berfokus pada berbagai jenis produk kursi tamu, sofa, lemari, kitchen set, bedroom, wardrobe room dan lain-lain. Perusahaan Anugah Al-baghdadi Mebel juga bergerak di bidang custom furniture manufacture, yaitu menawarkan jasa pembuatan custom furniture dengan ragam pilihan material sesuai permintaan pelanggan dan menjadi distributor di beberapa toko mebel. Secara umum penelitian ini bertujuan untuk mengetahui dan menjelaskan pengaruh kualitas pelayanan, lokasi dan word of mouth terhadap keputusan pembelian pada Anugerah Albaghdadi Mebel Karawang. Metode penelitian ini dengan menggunakan metode deskriptif dan verifikatif. Variabel diukur menggunakan instrumen kuesioner dan skala pengukuran yang digunakan adalah skala Likert. Sampel dikumpulkan dengan menggunakan metode Sampling accidental dengan jumlah sampel 92 responden dari populasi 1.215 orang. Teknik analisis data yang digunakan yaitu teknik Analisis Rentang Skala dan Analisis Jalur dengan bantuan Method of Successive Interval (MSI). Dari hasil analisis penelitian ini diperoleh beberapa kesimpulan yaitu

1. Hubungan antara Kualitas Pelayanan dengan Lokasi memiliki tingkat hubungan yang kuat.

2. Hubungan antara Kualitas Pelayanan dengan Word of Mouth memiliki tingkat hubungan yang sedang.

3. Hubungan antara Lokasi dengan Word of Mouth memiliki tingkat hubungan yang kuat.

4. Terdapat pengaruh parsial Kualitas Pelayanan, Lokasi dan Word of Mouth terhadap keputusan pembelian.

5. Terdapat pengaruh simultan antara Kualitas Pelayanan, Lokasi dan Word of Mouth terhadap Keputusan Pembelian.

6. Total Pengaruh Kualitas Pelayanan, Lokasi dan Word of Mouth memiliki kontribusi terhadap Keputusan Pembelian sebesar $83 \%$ sedangkan sisanya $17 \%$ merupakan kontribusi variabel lain $(\varepsilon)$ yang tidak diteliti.

Kata kunci : Kualitas Pelayanan, Lokasi, Word of Mouth, Keputusan Pembelian.
\end{abstract}

\begin{abstract}
Anugerah Al-baghdadi Mebel is a furniture company that focuses on various types of guest chairs, sofas, cabinets, kitchen sets, bedroom, wardrobe rooms and others. Anugerah Albaghdadi mebel is also engaged in custom furniture manufacture, namely offering custom furniture manufacturing services with a variety of material choices according to customer demand and becoming distributors in several furniture stores. In general, this study aims to find out and explain the effect of service quality, location and word of mouth on purchasing decisions at Anugerah Al-baghdadi Mebel Karawang. This research method uses descriptive and verification methods. Variables were measured using a questionnaire instrument and the measurement scale used was a Likert scale. Samples were collected using accidental
\end{abstract}


sampling method with a sample of 92 respondents from a population of 1,215 people. Data analysis techniques used are Scale Analysis and Path Analysis techniques with the help of Method of Successive Interval (MSI). From the research analysis there are some conclusion that:

1. The relationship between Service Quality and Location has a strong level of relationship.

2. The relationship between Service Quality with Word of Mouth has a moderate level of relationship.

3. The relationship between Location and Word of Mouth has a strong level of relationship.

4. There is a partial influence of Service Quality, Location and Word of Mouth on purchasing decisions.

5. There is a simultaneous influence between Service Quality, Location and Word of Mouth on Purchase Decisions.

6. Total Influence of Service Quality, Location and Word of Mouth contributed to the Purchasing Decision of $83 \%$ while the remaining $17 \%$ was the contribution of other variables $(\varepsilon)$ which were not examined.

Keywords: Service Quality, Location, Word of Mouth, Purchase Decision. 


\section{PENDAHULUAN}

Mebel merupakan salah satu kebutuhan dalam setiap rumah. Fungsinya tak hanya untuk memperindah interior dalam rumah, tapi juga untuk sebuah estetika yang mencitrakan kepribadian si pemilik rumah, selain fungsi utamanya yang menjadi alat untuk membantu kebutuhan sehari-hari. Usaha mebel telah lama dikenal di Indonesia karena merupakan budaya turun temurun. Industri permebelan di Indonesia didominasi oleh usaha kecil dan menengah (UKM), tetapi kebanyakan adalah usaha mikro/rumah tangga. Banyak dari mereka bekerjasama dengan industri - industri besar atau perusahaan-perusahaan pemasaran (trading houses). Industri olahan kayu Indonesia telah mampu menyerap tenaga kerja baik langsung maupun tidak langsung mencapai 4 juta jiwa. Produk olahan kayu ini juga menyumbang devisa dari ekspor yang nilainya mencapai US\$ 1,6 miliar, dimana 40\% di ekspor ke negara-negara di kawasan Amerika Latin dan Eropa Timur (Himpunan Industri Mebel Kerajinan Indonesia 2016). Kebutuhan konsumen yang terus meningkat, menjadi peluang bisnis. Hal tersebut menjadi dasar pemikiran para pelaku usaha untuk memenuhi kebutuhan, keinginan, dan harapan konsumen sehingga tidak berpaling ke pesaing meski terjadi perubahan keputusan pembelian konsumen merupakan salah satu bagian dari konsumen (consumen behavior) yang tercipta. Menurut Leon G. Schiffman \& Leslie lazar Kanuk dialih bahasakan oleh Zoelkifli Kasip (2008:485), Keputusan pembelian konsumen adalah seleksi terhadap dua pilihan alternatif atau lebih dengan perkataan lain pilihan alternatif harus tersedia bagi seseorang ketika mengambil keputusan pembelian atau tidak. Keputusan pembelian menjadi suatu hal yang penting untuk diperhatikan karena hal ini tentu akan menjadi suatu pertimbangan bagaimana suatu strategi pemasaran yang akan dilakukan oleh perusahaan berikutnya. Perusahaan dalam memasarkan barang/jasa sangat tergantung dan harus benar-benar memperhatikan kualitas pelayanan yang akan diberikan, penentuan lokasi perusahaan dan word of mouth dari perusahaan kita berjalan efektif atau tidak kepada pelanggan karena hal itu merupakan bagian yang penting untuk mempengaruhi keputusan pembelian konsumen.

Menurut Kotler dan Keller (2012: 131) kualitas pelayanan adalah kemampuan perusahaan untuk memuaskan kebutuhan dan keinginan konsumen. Jika kualitas pelayanan yang diberikan kepada konsumen sesuai dengan harapan konsumen, maka kualitas pelayanan mampu mempengaruhi keputusan pembelian konsumen dengan baik, tetapi jika kualitas pelayanan yang diberikan kepada konsumen tidak sesuai dengan apa yang diharapkan oleh konsumen maka kualitas pelayanan tidak akan mampu mempengaruhi keputusan pembelian konsumen dan keputusan pembeliannya cenderung lambat. 
Faktor lokasi merupakan salah satu faktor krusial yang berpengaruh terhadap kesuksesan suatu jasa, karena lokasi erat kaitannya dengan pasar potensial penyedia jasa untuk mempengaruhi keputusan pembelian konsumen (Tjiptono dan Chandra, 2005). Lokasi yang mudah dijangkau oleh konsumen dan dekat dengan pusat keramaian merupakan lokasi yang tepat untuk suatu usaha, termasuk usaha di bidang mebel. Sebelum seseorang atau sekelompok orang memutuskan untuk membeli produk mebel, mereka akan mempertimbangkan lokasi terlebih dahulu. Dalam memasarkan produknya, perusahaan memerlukan promosi seperti suatu komunikasi dengan para konsumen atau masyarakat pada umumnyauntuk mampu mempengaruhi konsumen dalam proses keputusan pembeliannya. Karena dengan adanya promosi tersebut maka konsumen dapat mengetahui produk yang ditawarkan oleh perusahaan. Salah satu caranya adalah Word of mouth. Marketing Association (WOMMA) menyatakan word of mouth merupakan usaha pemasaran yang memicu konsumen untuk membicarakan, mempromosikan, merekomendasikan dan menjual produk atau merek kepada pelanggan serta calon konsumen. Word of mouth merupakan sesuatu yang banyak dibicarakan oleh masyarakat, pembicaraan terjadi dikarenakan ada kontroversi yang membedakan dengan hal-hal yang biasa dan normal dilihat orang (www.womma.com).

Anugerah Al-baghdadi Mebel merupakan perusahaan mebel yang berfokus pada berbagai jenis produk kursi tamu, sofa, lemari, kitchen set, bedroom, wardrobe room dan lain-lain. Perusahaan Anugah Al-baghdadi Mebel juga bergerak di bidang custom furniture manufacture, yaitu menawarkan jasa pembuatan custom furniture dengan ragam pilihan material sesuai permintaan pelanggan dan menjadi distributor di beberapa toko mebel.

Sebelumnya peneliti melakukan penelitian terlebih dahulu dengan mewawancarai terhadap beberapa konsumen yang datang ke workshop Anugerah Al-baghdadi Mebel Karawang. Beberapa konsumen tersebut menyatakan bahwa kualitas produk AAM sangat baik dan menarik, harga produknya terjangkau dan sesuai dengan kualitasnya, .

Namun satu tahun terakhir, AAM mengalami sedikit masalah tentang jumlah penjualan yang mengalami penurunan yang cukup signifikan, kurang efektifnya promosi, lokasi yang tidak mudah dijangkau, tempat parkir yang sempit dan kualitas pelayanan karyawan belum maksimal kepada konsumen. Perusahaan harus memperhatikan kekurangannya tersebut diatas karena akan mempengaruhi keputusan pembelian konsumen semakin menurun. Oleh karena itu, Anugerah Albaghdadi Mebel harus mampu melakukan perubahan strategi dan mampu mengimbangi para kompetitor. 
Berdasarkan uraian di atas, maka penulis merasa tertarik untuk melakukan penelitian tentang kualitas pelayanan, lokasi, word of mouth dan keputusan pembelian yang dilakukan di Anugerah Al-baghdadi Mebel. Maka didalam penyusunan penelitian ini, penulis mengambil judul : PENGARUH KUALITAS PELAYANAN, LOKASI DAN WORD OF MOUTH TERHADAP KEPUTUSAN PEMBELIAN PADA ANUGERAH ALBAGHDADI MEBEL KARAWANG.

\section{Identifikasi Masalah}

Berdasarkan latar belakang penelitian, maka masalah tersebut dapat diidentifikasi sebagai berikut :

1. Nilai ekspor mebel Indonesia yang masih tertinggal jauh dengan negara-negara pesaing di Asia lainnya seperti China dan Vietnam.

2. Nilai ekspor mebel indonesia pada tahun 2016 yang mengalami penurunan dari tahun sebelumnya.

3. Pasar domestik mebel yang semakin digerus produk mebel impor.

4. Industri mebel di Indonesia yang masih terpusat pada suatu daerah saja, yaitu daerah provinsi Jawa tengah tepatnya di kota Jepara.

5. Menurunnya jumlah penjualan Anugerah Al-baghdadi Mebel Karawang dari tahun 2015 2016.

6. Anugerah Al-baghdadi Mebel tidak mudah dijangkau.

7. Anugerah Al-baghdadi Mebel tidak mudah terlihat (Plang).

8. Anugerah Al-baghdadi Mebel tidak memiliki parkir yang luas.

9. word of mouth pada Anugerah Al-baghdadi Mebel tidak berjalan efektif dikarenakan sedikitnya orang yang merekomendasikan melakukan pembelian produk Anugerah Albaghdadi Mebel.

10. Ruang untuk tamu yang ada pada Anugerah Al-baghdadi Mebel tidak nyaman.

11. Toilet Anugerah Al-baghdadi Mebel tidak bersih.

12. Proses pengiriman produk Anugerah Al-baghdadi Mebel tidak tepat waktu.

\section{Rumusan Masalah}

Berdasarkan dari uraian di atas, maka penulis merumuskan masalah yaitu sebagai berikut :

1. Bagaimana kualitas pelayanan Anugerah Al-baghdadi Mebel ? 
2. Bagaimana lokasi Anugerah Al-baghdadi Mebel ?

3. Bagaimana word of mouth produk Anugerah Al-baghdadi Mebel ?

4. Bagaimana keputusan pembelian produk Anugerah Al-baghdadi Mebel ?

5. Berapa besar korelasi antara kualitas pelayanan dan lokasi pada Anugerah Al-baghdadi Mebel ?

6. Berapa besar korelasi antara kualitas pelayanan dan word of mouth pada Anugerah Albaghdadi Mebel ?

7. Berapa besar korelasi antara lokasi dan word of mouth pada Anugerah Al-baghdadi Mebel ?

8. Seberapa besar pengaruh kualitas pelayanan, lokasi dan word of mouth secara parsial terhadap keputusan pembelian pada Anugerah Al-baghdadai Mebel ?

9. Seberapa besar pengaruh kualitas pelayanan, lokasi dan word of mouth secara simultan terhadap keputusan pembelian pada Anugerah Al-baghdadai Mebel ?

\section{Tujuan Penelitian}

Sesuai dengan identifikasi masalah, maka yang menjadi tujuan penelitian ini adalah untuk menyelesaikan masalah serta mengetahui dan menganalisis :

1. Kualitas pelayanan Anugerah Al-baghdadi Mebel.

2. Lokasi Anugerah Al-baghdadi Mebel.

3. Word of mouth produk Anugerah Al-baghdadi Mebel.

4. Keputusan pembelian produk Anugerah Al-baghdadi Mebel.

5. Korelasi antara kualitas pelayanan dan lokasi.

6. Korelasi antara kualitas pelayanan dan word of mouth.

7. korelasi antara lokasi dan word of mouth.

8. Besarnya pengaruh kualitas pelayanan, lokasi dan word of mouth secara parsial terhadap keputusan pembelian pada Anugerah Al-baghdadi Mebel.

9. Besarnya pengaruh kualitas pelayanan, lokasi dan word of mouth secara simultan terhadap keputusan pembelian pada Anugerah Al-baghdadi Mebel.

\section{TINJAUAN PUSTAKA}

\section{Kualitas Pelayanan}

Menurut Kotler dan Keller (2012: 131), mendefinisikan kualitas pelayanan adalah kemampuan perusahaan untuk memuaskan kebutuhan dan keinginan konsumen. Berdasarkan 
definisi ini, kualitas pelayanan ditentukan oleh kemampuan perusahaan memenuhi kebutuhan dan keinginan konsumen sesuai dengan ekspektasi konsumen.

Menurut Fandhy Tjiptono (2007: 59) Kualitas pelayanan adalah tingkat keunggulan yang diharapkan dan pengendaliannya atas tingkat keunggulan tersebut untuk memenuhi keinginan pelanggan. Konsumen akan menilai kualitas sebuah pelayanan yang dirasakan berdasarkan apa yang mereka deskripsikan dalam benak mereka. Konsumen akan beralih ke penyedia jasa lain yang lebih mampu memahami kebutuhan spesifik konsumen dan memberikan layanan yang lebih baik.

Pengukuran terhadap kualitas pelayanan dinyatakan dalam lima dimensi kualitas pelayanan jasa. Lima dimensi kualitas pelayanan tersebut menurut Kotler dan Keller (2012:374), adalah :

1. Bukti Fisik (Tangible)

2. Empati (Empathy)

3. Kehandalan (Reliability)

4. Daya Tanggap (Responsiveness)

5. Jaminan (Assurance)

\section{Lokasi}

Menurut (Fitzsimmons,1994) Lokasi berpengaruh terhadap dimensi-dimensi strategik, seperti fleksibilitas, competitive positioning, manajemen permintaan, dan focus strategic

Menurut (Tjiptono dan Chandra, 2005) lokasi merupakan salah satu faktor krusial yang berpengaruh terhadap kesuksesan suatu jasa, karena lokasi erat kaitannya dengan pasar potensial penyedia jasa.

Menurut Fandy Tjiptono dan Gregorius Chandra (2005), pemilihan lokasi fisik memerlukan pertimbangan cermat terhadap faktor-faktor berikut:

1. Akses, yaitu lokasi yang dilalui mudah dijangkai sarana transportasi umum.

2. Visibilitas, yaitu lokasi atau tempat yang dapat dilihat dengan jelas dari jarak pandang normal.

3. Lalu lintas, menyangkut dua pertimbangan utama, yaitu :

(1) Banyak orang yang berlalu lalang bisa memberikan peluang besar terjadinya impulse buying, yaitu keputusan pembelian yang sering terjadi spontan atau tanpa perencanaan dan

(2) Kepadatan dan kemacetan lalu lintas bisa juga menjadi hambatan.

4. Tempat parkir yang luas, nyaman dan aman.

5. Ekspansi, yaitu tersedia tempat yang cukup luas untuk perluasan usaha di kemudian hari. 
6. Lingkungan, yaitu daerah sekitar yang mendukung jasa yang ditawarkan.

7. Kompetisi, yaitu lokasi pesaing. Dalam menentukan lokasi sebuah usaha, perlu dipertimbangkan apakah di jalan atau daerah tersebut telah terdapat banyak usaha yang sejenis atau tidak.

8. Peraturan Pemerintah yang berisi ketentuan untuk mengatur lokasi dari sebuah usaha-usaha tertentu, misalnya bengkel kendaraan bermotor dilarang berlokasi yang terlalu berdekatan dengan tempat ibadah.

\section{Word of mouth}

Marketing Association (WOMMA) menyatakan word of mouth merupakan usaha pemasaran yang memicu konsumen untuk membicarakan, mempromosikan, merekomendasikan dan menjual produk atau merek kepada pelanggan serta calon konsumen

Kotler dan Keller (2012:546) mendefinisikan word of mouth adalah Word of mouth marketing is people to people oral, written, or electronic communications that relate to the merits or experiences of purchasing or using product service

Sernovits(2012:1) mendefinisikan word of mouth adalah Word of mouth marketing is about real people talking each other-customer to customer, instead of marketing doing the talking

Sernovits (2012:37) menyatakan ada lima elemen-elemen (Five Ts) yang dibutuhkan untuk word of mouth agar dapat menyebar yaitu :

1. Talkers yaitu kita harus mengetahui siapa pembicara dalam hal ini pembicara adalah konsumen kita yang telah mengkonsumsi produk atau jasa yang telah kita berikan, terkadang orang lain cenderung dalam memilih atau memutuskan suatu produk tergantung kepada konsumen yang telah berpengalaman menggunakan produk atau jasa tersebut yang bisa disebut dengan referal pihak yang merekomendasikan suatu prosuk atau jasa.

2. Topics yaitu suatu word of mouth karena tercipta suatu pesan atau perihal yang membuat mereka berbicara mengenai produk atau jasa, seperti halnya pelayanan yang diberikan, karena produk kita mempunyai keunggulan tersendiri, tentang perusahaan kita, lokasi yang strategis.

3. Tools yaitu kita mengetahui pesan atau perihal yang membuat mereka berbicara mengenai produk atau jasa tersebut dibutuhkan suatu alat untuk membantu agar pesan tersebut dapat berjalan, seperti website game yang diciptakan untuk orang-orang bermain, contoh produk gratis, postcarrds, brosur, spanduk, melalui iklan di radio apa saja alat yang bisa membuat orang mudah membicarakan atau menularkan produk anda kepada temannya. 
4. Taking Part atau partisipasi perusahaan yaitu suatu partisipasi perusahaan seperti halnya dalam menanggapi respon pertanyaan-pertanyaaan mengenai produk atau jasa tersebut dari para calon konsumen dengan menjelaskan secara lebih jelas dan terperinci mengenai produk atau jasa tersebut, melakukan follow up ke calon konsumen sehingga mereka melakukan suatu proses pengambilan keputusan.

5. Tracking atau pengawasan akan hasil WOM marketing perusahaan setelah suatu alat tersebut berguna dalam proses word of mouth dan perusahaan pun cepat tanggap dalam merespon calon konsumen, perlu pula pengawasan akan word of mouth yang telah ada tersebut yaitu dengan melihat hasil seperti dalam kotak saran sehingga terdapat informasi banyaknya word of mouth positif atau word of mouth negatif dari para konsumen.

\section{Keputusan Pembelian}

Menurut Leon G. Schiffman \& Leslie lazar Kanuk dialih bahasakan oleh Zoelkifli Kasip (2008:485), Keputusan pembelian konsumen adalah seleksi terhadap dua pilihan alternatif atau lebih dengan perkataan lain pilihan alternatif harus tersedia bagi seseorang ketika mengambil keputusan pembelian atau tidak.

Menurut Kotler dan Keller (2009:184-190) yang telah dialih bahasakan oleh Bob Sabran periset pemasaran telah mengembangkan "model tingkat" proses keputusan pembelian konsumen melalui lima tahap yaitu :

1. Pengenalan masalah

2. Pencarian Informasi

3. Evaluasi Alternatif

4. Keputusan Pembelian

5. Perilaku Pasca Pembelian

\section{Paradigma Penelitian}

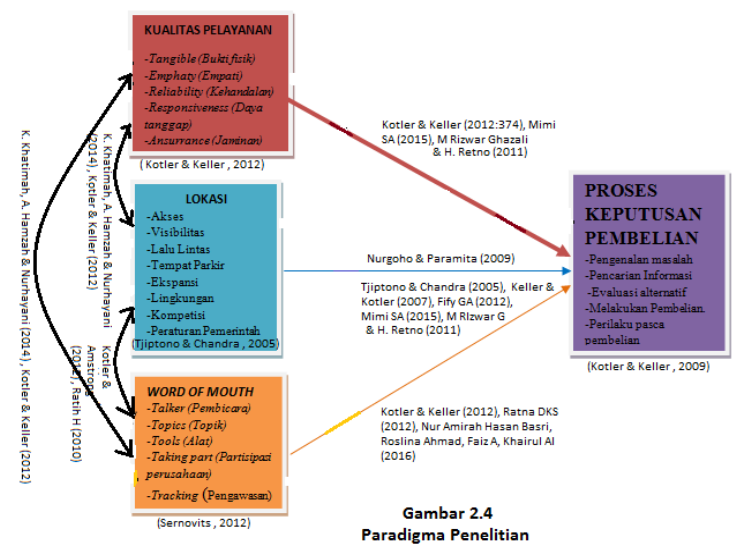


Gambar 1. Paradigma Penelitian

\section{Hipotesa Penelitian}

Dalam penelitian ini hipotesis yang diajukan adalah :

1. Terdapat korelasi antara kualitas pelayanan dan lokasi pada AAM Mebel Karawang.

2. Terdapat korelasi antara kualitas pelayanan dan word of mouth pada AAM Mebel Karawang.

3. Terdapat korelasi antara lokasi dan word of mouth pada AAM Mebel Karawang.

4. Terdapat pengaruh kualitas pelayanan, lokasi dan word of mouth secara parsial terhadap keputusan pembelian konsumen pada AAM Mebel Karawang.

5. Terdapat pengaruh kualitas pelayanan, lokasi dan word of mouth secara simultan terhadap keputusan pembelian konsumen pada AAM Mebel Karawang.

\section{METODE PENELITIAN}

\section{Jenis Penelitian}

Pada penelitian ini menggunakan metode kuantitatif dengan tujuan penelitian yang berupaya untuk memberikan generalisasi mengenai pengaruh kualitas pelayanan, lokasi dan word of mouth terhadap keputusan pembelian.

Secara deskriptif penelitian ini bertujuan untuk memperoleh gambaran mengenai variabel Kualitas Pelayanan, variabel Lokasi dan variabel Word of mouth sebagai variabel bebasnya dan Keputusan Pembelian sebagai variabel terikat. Sedangkan secara verifikatif bertujuan untuk menguji hipotesis dengan perhitungan statistik.

\section{Waktu dan Tempat Penelitian}

Penelitian ini dilaksanakan pada rentang waktu bulan mei 2017 sampai dengan bulan oktober 2017, dan tempat penelitian di Anugerah Al-baghdadi Mebel Karawang.

\section{Operasionalisasi Variabel}

Dalam penelitian ini peneliti menggunakan tiga variabel yaitu tiga variabel bebas $\left(\mathrm{X}_{1}\right.$, $\mathrm{X}_{2}$ dan $\mathrm{X}_{3}$ ) dan satu variabel terikat $(\mathrm{Y})$. Dalam hal ini variabel $\mathrm{X}_{1}$ adalah kualitas pelayanan, variabel $\mathrm{X}_{2}$ adalah Lokasi dan variabel $\mathrm{X}_{3}$ adalah Word of mouth merupakan variabel yang mempengaruhi variabel Y yaitu Keputusan Pembelian di Anugerah Al-baghdadi Mebel Karawang. 


\section{Sumber Dan Cara Penentuan Data/Informasi}

Jenis data yang digunakan dalam penelitian ini adalah data primer dan data sekunder.

1. Data Primer

Pengumpulan data primer dalam penelitian ini melalui cara menyebarkan kuesioner kepada konsumen yang datang ke Anugerah Al-baghdadi Mebel.

2. Data Sekunder

Dalam hal ini penulis mengumpulkan data secara library research, yaitu dengan melihat buku-buku (literature) yang berhubungan dengan masalah penelitian dan dapat melengkapi/mendukung data primer.

\section{Populasi Dan Sampel}

Dalam penelitian ini populasinya adalah konsumen Anugerah Al-baghdadi Mebel Karawang. Populasi yang diambil dari jumlah data penjualan konsumen tahun 2016, yaitu sekitar 1.215 orang.

Adapun peneliti menggunakan rumus Slovin. Rumus Slovin untuk menentukan sampel adalah :

$$
\mathrm{n}=\frac{N}{1+\mathrm{N}(e)^{2}}
$$

Keterangan :

$\mathrm{n}=$ Ukuran sampel/jumlah responden

$\mathrm{N}=$ Ukuran populasi

$\mathrm{e}=$ Persentase kelonggaran ketelitian kesalahan pengambilan sampel yang masih bisa ditolerir; e $=0,05$

Jumlah populasi dalam penelitian ini adalah 1.215 orang, sehingga persentase kelonggaran yang digunakan adalah 10\%. Maka untuk mengetahui sampel penelitian, berikut perhitungannya :

$$
\mathrm{n}=\frac{1.215}{1+1.215(0,1)^{2}}=92,39544 \text { dibulatkan } 92
$$

Jumlah sampel dibulatkan menjadi 92 orang

Berdasarkan perhitungan di atas, sampel yang menjadi responden dalam penelitian ini sebanyak 92 orang, sampel diambil berdasarkan teknik probability sampling, simple random sampling, dimana peneliti memberikan peluang yang sama bagi setiap unsur (anggota) 
populasi untuk dipilih menjadi anggota sampel yang dilakukan secara acak tanpa memperhatikan strata yang ada dalam populasi itu sendiri.

\section{Teknik Pengumpulan Data}

Pada penelitian ini menggunakan metode pengumpulan data sebagai berikut:

1. Penelitian Lapangan (Field Research)

Dalam penelitian lapangan tersebut penulis menggunakan beberapa prosedur yaitu :

a. Angket

b. Observasi

c. Wawancara

Pada penelitian ini, penulis melakukan wawancara terhadap konsumen Anugerah Albaghdadi Mebel Karawang.

2. Penelitian Kepustakaan (Library Research)

Yaitu mencari, mempelajari dan mengumpulkan teori serta bahan-bahan yang mendukung bagi penulis dengan mempelajari informasi dari beberapa literature yang berkaitan dengan masalah yang sedang diteliti penulis

\section{Rancangan Analisis dan Uji Hipotesis}

\section{Rancangan Analisis Deskriptif}

Analisis deskriptif menggunakan skala ordinal dan rentang skala untuk menganalisis data dengan cara menggambarkan Kualitas Pelayanan, Lokasi dan Word of mouth terhadap Keputusan Pembelian di Anugerah Al-baghdadi Mebel Karawang

Untuk menentukan skala prioritas dari setiap variabel yang diukur selanjutnya dihitung skala dari skor yang diukur dengan menggunakan analisis rentang skala.

\section{Rancangan Analisis Verifikatif}

Menurut Juliansyah Noor (2012:20), pengertian metode penelitian verifikatif adalah metode penelitian yang digunakan untuk menguji kebenaran dari sesuatu (ilmu pengetahuan) yang telah ada". Analisis verifikatif yang digunakan dalam penelitian ini menggunakan analisis korelasi produk moment, analisis regresi linier berganda, dan analisis teknik jalur (path analysis).

\section{Uji Hipotesis}

\section{Uji Hipotesis (Uji t)}


Untuk mengetahui besarnya pengaruh masing-masing variabel independen secara individual (parsial) terhadap variabel dependen. Hasil uji thitung ini ada pada output perangkat lunak, dapat dilihat pada tabel coefficient level of significance yang digunakan sebesar 5\% atau (a) = 0,05. Apabila $t_{\text {hitung }}>t_{\text {tabel }}$ maka $H_{0}$ ditolak dan $H_{a}$ diterima, artinya variabel independen secara parsial tidak mempunyai pengaruh yang signifikan terhadap variabel dependen. Untuk yang memakai variabel simultan harus menambahkan uji $\mathrm{F}$ dengan tujuan untuk menentukan apakah suatu dugaan hipotesis 3 variabel bebas secara bersama-sama terhadap variabel terikat tersebut sebaiknya diterima atau ditolak. Pengujian ini dilakukan untuk mengetahui signifikasi atau tidaknya pengaruh variabel bebas secara bersama-sama / simultan terhadap variabel terikatnya. Apabila hasil uju $\mathrm{f}_{\text {hitung }}$ lebih dari $\mathrm{f}_{\text {tabel }}$ berarti variabel cikup signifikan untuk menjelaskan variabel terikat.

\section{HASIL PENELITIAN DAN PEMBAHASAN}

\section{Analisis Validitas Data}

Berdasarkan hasil uji validitas pada semua variabel dengan menggunakan SPSS terlihat pada kolom corrected item-total correlation dan hasilnya tidak ada yang negatif dan lebih dari 0,3 untuk semua pernyataan.

\section{Analisis Reliabilitas Data}

Dengan menggunakan SPSS 19, hasil uji reliabilitas dari semua variabel menunjukkan sudah reliable karena nilai variabel tersebut sudah diatas 0,7 .

\section{Uji Normalitas}

Dengan menggunakan SPSS 19, hasil uji normalitas dari semua variabel menunjukan nilai signifikan >0,05, sehingga hasilnya menunjukkan semua variabel berdistribusi normal.

\section{Analisis Deskriptif}

\section{Kualitas Pelayanan (X1)}

Kualitas Pelayanan mencapai nilai total skor 2540 dengan nilai rata-rata skor 282,2 berada pada nilai rentang skala 239,2 - 312,8 dengan kategori cukup setuju.

\section{Lokasi (X2)}

Lokasi mencapai nilai total skor 2577 dengan nilai rata-rata skor 286,3 berada pada nilai rentang skala 239,2 - 312,8 dengan kategori cukup setuju.

\section{Word of Mouth (X3)}

Word of mouth mencapai nilai total skor 3017 dengan nilai rata-rata skor 301,7 berada pada nilai rentang skala 239,2 - 312,8 dengan kategori cukup setuju.

\section{Keputusan Pembelian (Y)}


Keputusan Pembelian mencapai nilai total skor 1368 dengan nilai rata-rata skor 273,6 berada pada nilai rentang skala 239,2 - 312,8 dengan kategori cukup setuju.

\section{Pengujian Hipotesis}

\section{Korelasi antara Kualitas Pelayanan $\left(\mathbf{X}_{1}\right)$ dan Lokasi $\left(\mathbf{X}_{2}\right)$}

Korelasi Kualitas Pelayanan $\left(\mathrm{X}_{1}\right)$ dengan Lokasi $\left(\mathrm{X}_{2}\right)$ mempunyai nilai koefisien korelasi (r) sebesar 0,649 dan jika diinterpretasikan dengan keeratan hubungan kedua variabel ini mempunyai tingkat hubungan yang kuat (Sugiyono, 2014:84) dan searah karena nilainya positif

\section{Korelasi antara Kualitas pelayanan (X1) dan Word of mouth (X3)}

Korelasi Kualitas Pelayanan $\left(\mathrm{X}_{1}\right)$ dengan Word of mouth $\left(\mathrm{X}_{3}\right)$ mempunyai nilai koefisien korelasi (r) sebesar 0,541 dan jika diinterpretasikan dengan keeratan hubungan kedua variabel ini mempunyai tingkat hubungan yang sedang (Sugiyono, 2014:84) dan searah karena nilainya positif.

\section{Korelasi antara Lokasi (X2) dan Word of mouth (X3}

Korelasi Lokasi $\left(\mathrm{X}_{2}\right)$ dengan Word of mouth $\left(\mathrm{X}_{3}\right)$ mempunyai nilai koefisien korelasi $(\mathrm{r})$ sebesar 0,697 dan jika diinterpretasikan dengan keeratan hubungan kedua variabel ini mempunyai tingkat hubungan yang kuat (Sugiyono, 2014:84) dan searah karena nilainya positif.

\section{Hipotesis Pengaruh Variabel Secara Parsial}

1) Hipotesis pengaruh kualitas pelayanan $\left(\mathrm{X}_{1}\right)$ terhadap keputusan pembelian $(\mathrm{Y})$

Besaran pengaruh parsial Kualitas Pelayanan $\left(\mathrm{X}_{1}\right)$ terhadap Keputusan Pembelian (Y) mempunyai nilai koefisien jalur sebesar 0,139 atau mempunyai nilai koefisien determinasi sebesar 0,093 atau berpengaruh sebesar 9,3\%.

2) Hipotesis pengaruh lokasi $\left(\mathrm{X}_{2}\right)$ terhadap keputusan pembelian $(\mathrm{Y}) \quad$ Pengaruh parsial Lokasi $\left(\mathrm{X}_{2}\right)$ terhadap Keputusan Pembelian (Y) mempunyai nilai koefisien jalur sebesar 0,6 atau mempunyai nilai koefisien determinasi sebesar 0,528 atau berpengaruh sebesar $52,8 \%$.

3) Hipotesis pengaruh word of mouth $\left(\mathrm{X}_{3}\right)$ terhadap keputusan pembelian $(\mathrm{Y})$

Pengaruh parsial Word of mouth $\left(\mathrm{X}_{3}\right)$ terhadap Keputusan Pembelian (Y) mempunyai nilai koefisien jalur sebesar 0,273 atau mempunyai nilai koefisien determinasi sebesar 0,209 atau berpengaruh sebesar 20,9\% . 


\section{Analisis Jalur ( Path Analysist)}

Berdasarkan hasil pengolahan data tersebut menunjukan bahwa nilai koefisien jalur sebesar 0,600 >0,273>0,139, maka dinyatakan bahwa variabel lokasi $\left(\mathrm{X}_{2}\right)$ lebih besar dan lebih dominan memberikan kontribusi terhadap keputusan pembelian dibandingkan dengan variabel word of mouth $\left(\mathrm{X}_{3}\right)$ dan variabel kualitas pelayanan $\left(\mathrm{X}_{1}\right)$.

\section{Hipotesis Pengaruh Variabel Secara Simultan}

Berdasarkan hasil penelitian ini menunjukan bahwa kualitas pelayanan, lokasi dan word of mouth memiliki kontribusi terhadap Keputusan pembelian (Y) sebesar 83\% sedangkan sisanya 0,170 atau sebesar $17 \%$ merupakan pengaruh kontribusi variabel lain $(\varepsilon)$ yang tidak diteliti. Variabel Kualitas Pelayanan $\left(\mathrm{X}_{1}\right)$ berpengaruh signifikan terhadap Keputusan Pembelian (Y), dengan kriteria uji nilai Sig. $(0,02)<\alpha(0,05)$ dan thitung $(2,36)>$ t tabel (1,662). Artinya Ho ditolak. Hal ini dapat dijelaskan bahwa kualitas pelayanan mempunyai nilai signifikansi atau bermakna terhadap keputusan pembelian. Variabel Lokasi $\left(\mathrm{X}_{2}\right)$ berpengaruh signifikan terhadap Keputusan Pembelian (Y), dengan kriteria uji nilai Sig. $(0,000)<\alpha(0,05)$ dan $\mathrm{t}$ hitung $(8,73)>\mathrm{t}$ tabel $(1,662)$. Artinya Ho ditolak. Hal ini menunjukan bahwa lokasi mempunyai nilai signifikansi atau bermakna terhadap keputusan pembelian. Variabel Word of mouth $\left(\mathrm{X}_{3}\right)$ berpengaruh signifikan terhadap Keputusan Pembelian (Y), dengan kriteria uji nilai Sig. $(0,000)<\alpha(0,05)$ dan $t$ hitung $(4,39)>t$ tabel $(1,662)$. Artinya Ho ditolak. Hal ini dapat dijelaskan bahwa word of mouth mempunyai nilai signifikansi atau bermakna terhadap keputusan pembelian. Kualitas Pelayanan $\left(\mathrm{X}_{1}\right)$, Lokasi $\left(\mathrm{X}_{2}\right)$, dan Word of Mouth $\left(\mathrm{X}_{3}\right)$ berpengaruh signifikan terhadap Keputusan Pembelian (Y), diperoleh nilai Sig. $0,000<\alpha(0,05)$ dan F hitung $(143,514)>$ F tabel $(2,71)$.

\section{Pembahasan Deskriptif}

Adapun pembahasan dari metode deskriptif mengenai masing-masing variabel dalam penelitian ini dapat diuraikan sebagai berikut.

1. Kualitas Pelayanan mencapai nilai total skor 2540 dengan nilai rata-rata skor 282,2 berada pada nilai rentang skala 239,2 - 312,8 dengan kategori cukup setuju. Artinya konsumen memberikan respon yang cukup baik tetapi belum optimal terhadap kualitas pelayanan yang diterapkan selama ini oleh Anugerah Al-baghdadi Mebel Karawang

2. Lokasi mencapai nilai total skor 2577 dengan nilai rata-rata skor 286,3 berada pada nilai rentang skala 239,2 - 312,8 dengan kategori cukup setuju. Artinya konsumen 
memberikan respon yang cukup baik tetapi belum optimal terhadap lokasi Anugerah Albaghdadi Mebel Karawang

3. Word of mouth mencapai nilai total skor 3017 dengan nilai rata-rata skor 301,7 berada pada nilai rentang skala 239,2 - 312,8 dengan kategori cukup setuju. Artinya konsumen memberikan respon yang cukup baik tetapi belum optimal terhadap word of mouth yang diterapkan selama ini di Anugerah Al-baghdadi Mebel Karawang.

4. Keputusan Pembelian mencapai nilai total skor 1368 dengan nilai rata-rata skor 273,6 berada pada nilai rentang skala 239,2 - 312,8 dengan kategori cukup setuju. Artinya konsumen memberikan respon cukup baik tetapi belum optimal terhadap keputusan pembelian pada Anugerah Al-baghdadi Mebel Karawang.

\section{Pembahasan Verifikatif}

1. Korelasi Kualitas Pelayanan ( $x_{1}$ ) dengan Lokasi (x2) mempunyai nilai koefisien korelasi (r) sebesar 0,649 dan jika diinterpretasikan dengan keeratan hubungan kedua variabel ini mempunyai tingkat hubungan yang kuat dan searah karena nilainya positif.

2. Korelasi Kualitas Pelayanan $\left(\mathrm{X}_{1}\right)$ dengan Word of mouth $\left(\mathrm{X}_{3}\right)$ mempunyai nilai koefisien korelasi (r) sebesar 0,541 dan jika diinterpretasikan dengan keeratan hubungan kedua variabel ini mempunyai tingkat hubungan yang sedang dan searah karena nilainya positif.

3. Korelasi Lokasi $\left(\mathrm{X}_{2}\right)$ dengan Word of mouth $\left(\mathrm{X}_{3}\right)$ mempunyai nilai koefisien korelasi $(\mathrm{r})$ sebesar 0,697 dan jika diinterpretasikan dengan keeratan hubungan kedua variabel ini mempunyai tingkat hubungan yang kuat dan searah karena nilainya positif.

4. Pengaruh parsial kualitas pelayanan $\left(\mathrm{X}_{1}\right)$ dan lokasi $\left(\mathrm{X}_{2}\right)$ dan word of mouth $\left(\mathrm{X}_{3}\right)$ terhadap keputusan pembelian (Y).

a. Pengaruh Parsial Kualitas Pelayanan $\left(\mathrm{X}_{1}\right)$ terhadap Keputusan Pembelian (Y) adalah sebesar 0,139. Hal ini menunjukkan pengaruh positif antara kualitas pelayanan $\left(\mathrm{X}_{1}\right)$ terhadap keputusan pembelian (Y).

b. Pengaruh Parsial Lokasi $\left(\mathrm{X}_{2}\right)$ terhadap Keputusan Pembelian (Y) adalah sebesar 0,6. Hal ini menunjukkan pengaruh positif antara lokasi $\left(\mathrm{X}_{2}\right)$ terhadap keputusan pembelian (Y).

c. Pengaruh Parsial Word of mouth $\left(\mathrm{X}_{3}\right)$ terhadap Keputusan Pembelian (Y) adalah sebesar 0,273. Hal ini menunjukkan pengaruh positif antara word of mouth $\left(\mathrm{X}_{2}\right)$ terhadap keputusan pembelian (Y). Karena 0,6 lebih besar dari 0,139 dan 0,273, maka dapat dinyatakan bahwa variabel lokasi lebih banyak memberikan pengaruh terhadap keputusan pembelian dibandingkan variable kualitas pelayanan dan word of mouth. 
5. Variabel Kualitas Pelayanan $\left(\mathrm{X}_{1}\right)$ berpengaruh signifikan terhadap Keputusan Pembelian (Y), dengan kriteria uji nilai Sig. $(0,02)<\alpha(0,05)$ dan $t$ hitung $(2,36)>t$ tabel $(1,662)$. Artinya Ho ditolak. Variabel Lokasi $\left(\mathrm{X}_{2}\right)$ berpengaruh signifikan terhadap Keputusan Pembelian (Y), dengan kriteria uji nilai Sig. $(0,000)<\alpha(0,05)$ dan t hitung $(8,73)>\mathrm{t}$ tabel $(1,662)$. Artinya Ho ditolak. Variabel Word of mouth $\left(\mathrm{X}_{3}\right)$ berpengaruh signifikan terhadap Keputusan Pembelian (Y), dengan kriteria uji nilai Sig. $(0,000)<\alpha$ $(0,05)$ dan $t$ hitung $(4,39)>t$ tabel $(1,662)$. Artinya Ho ditolak.

6. Kualitas Pelayanan $\left(\mathrm{X}_{1}\right)$, Lokasi $\left(\mathrm{X}_{2}\right)$, dan Word of Mouth $\left(\mathrm{X}_{3}\right)$ berpengaruh signifikan terhadap Keputusan Pembelian (Y), diperoleh nilai Sig. $0,000<\alpha(0,05)$ dan F hitung $(143,514)>$ F tabel $(2,71)$

\section{KESIMPULAN DAN SARAN}

\section{Kesimpulan}

Berdasarkan tujuan penelitian yang dikemukakan dan selanjutnya dibandingkan dengan hasil penelitian dan pembahasan maka dapat dibuat kesimpulan sebagai berikut:

1. Kualitas Pelayanan mencapai nilai total skor 2540 dengan nilai rata-rata skor 282,2 berada pada nilai rentang skala 239,2 - 312,8 dengan kategori cukup setuju. Artinya konsumen memberikan respon yang cukup baik tetapi belum optimal terhadap kualitas pelayanan yang diterapkan selama ini oleh Anugerah Al-baghdadi Mebel Karawang. Namun terdapat satu indikator yang menurut persepsi konsumen masih rendah dan nilainya terkecil yaitu indikator kebersihan toilet dengan skor 218.

2. Lokasi mencapai nilai total skor 2577 dengan nilai rata-rata skor 286,3 berada pada nilai rentang skala 239,2 - 312,8 dengan kategori cukup setuju. Artinya konsumen memberikan respon yang cukup baik tetapi belum optimal terhadap lokasi Anugerah Al-baghdadi Mebel Karawang. Namun terdapat satu indikator yang menurut persepsi konsumen masih rendah dan nilainya terkecil yaitu indikator luas tempat parkir dengan skor 242.

3. Word of mouth mencapai nilai total skor 3017 dengan nilai rata-rata skor 301,7 berada pada nilai rentang skala 239,2 - 312,8 dengan kategori cukup setuju. Artinya konsumen memberikan respon yang cukup baik tetapi belum optimal terhadap word of mouth yang diterapkan selama ini di Anugerah Al-baghdadi Mebel Karawang. Namun terdapat satu indikator yang menurut persepsi konsumen masih rendah dan nilainya terkecil yaitu indikator tersedia layanan customer service dengan skor 249.

4. Keputusan Pembelian mencapai nilai total skor 1368 dengan nilai rata-rata skor 273,6 berada pada nilai rentang skala 239,2 - 312,8 dengan kategori cukup setuju. Artinya 
konsumen memberikan respon cukup baik tetapi belum optimal terhadap keputusan pembelian pada Anugerah Al-baghdadi Mebel Karawang. Namun terdapat satu indikator yang menurut persepsi konsumen masih rendah dan nilainya terkecil yaitu indikator kesesuaian terhadap informasi produk dengan skor 242.

5. Korelasi Kualitas Pelayanan $\left(X_{1}\right)$ dengan Lokasi $\left(X_{2}\right)$ mempunyai nilai koefisien korelasi (r) sebesar 0,649 dan jika diinterpretasikan dengan keeratan hubungan kedua variabel ini mempunyai tingkat hubungan yang kuat dan searah karena nilainya positif. Ini menunjukan bahwa jika kualitas pelayanan meningkat maka lokasi juga akan meningkat. Sebaliknya jika lokasi meningkat maka kualitas pelayanan juga akan meningkat.

6. Korelasi Kualitas Pelayanan $\left(\mathrm{X}_{1}\right)$ dengan Word of mouth $\left(\mathrm{X}_{3}\right)$ mempunyai nilai koefisien korelasi (r) sebesar 0,541 dan jika diinterpretasikan dengan keeratan hubungan kedua variabel ini mempunyai tingkat hubungan yang sedang dan searah karena nilainya positif. Ini menunjukan bahwa jika kualitas pelayanan meningkat maka word of mouth juga akan meningkat. Sebaliknya jika word of mouth meningkat maka kualitas pelayanan juga akan meningkat.

7. Korelasi Lokasi $\left(\mathrm{X}_{2}\right)$ dengan Word of mouth $\left(\mathrm{X}_{3}\right)$ mempunyai nilai koefisien korelasi ( $\left.\mathrm{r}\right)$ sebesar 0,697 dan jika diinterpretasikan dengan keeratan hubungan kedua variabel ini mempunyai tingkat hubungan yang kuat dan searah karena nilainya positif. Ini menunjukan bahwa jika lokasi meningkat maka word of mouth juga akan meningkat. Sebaliknya jika word of mouth meningkat maka lokasi juga akan meningkat.

8. Besaran pengaruh parsial Kualitas Pelayanan $\left(\mathrm{X}_{1}\right)$ terhadap Keputusan Pembelian (Y) mempunyai nilai koefisien jalur sebesar 0,139 atau mempunyai nilai koefisien determinasi sebesar 0,093 atau berpengaruh sebesar 9,3\%. Sedangkan pengaruh parsial Penghargaan $\left(\mathrm{X}_{2}\right)$ terhadap Kinerja Karyawan (Y) mempunyai nilai koefisien jalur sebesar 0,6 atau mempunyai nilai koefisien determinasi sebesar 0,528 atau berpengaruh sebesar 52,8\%. Sedangkan pengaruh parsial Word of mouth $\left(\mathrm{X}_{3}\right)$ terhadap Keputusan Pembelian (Y) mempunyai nilai koefisien jalur sebesar 0,273 atau mempunyai nilai koefisien determinasi sebesar 0,209 atau berpengaruh sebesar 20,9\%. Selanjutnya berdasarkan hasil pengolahan data tersebut menunjukan bahwa nilai koefisien jalur sebesar 0,600>0,273>0,139, maka dinyatakan bahwa variabel lokasi $\left(\mathrm{X}_{2}\right)$ lebih besar dan lebih dominan memberikan kontribusi terhadap keputusan pembelian dibandingkan dengan variabel word of mouth $\left(\mathrm{X}_{3}\right)$ dan variabel kualitas pelayanan $\left(\mathrm{X}_{1}\right)$.

9. Nilai koefisien determinasi pengaruh simultan kualitas pelayanan, lokasi dan word of mouth sebesar 0,830. Sehingga dapat diartikan bahwa total pengaruh Motivasi Kerja $\left(\mathrm{X}_{1}\right)$, 
Penghargaan $\left(\mathrm{X}_{2}\right)$, dan Hukuman $\left(\mathrm{X}_{3}\right)$ terhadap kinerja karyawan sebesar 0,830 atau sebesar 83\%. Berdasarkan hasil penelitian ini menunjukan bahwa kualitas pelayanan, lokasi dan word of mouth memiliki kontribusi terhadap Keputusan pembelian (Y) sebesar $83 \%$ sedangkan sisanya 0,170 atau sebesar $17 \%$ merupakan pengaruh kontribusi variabel lain $(\varepsilon)$ yang tidak diteliti. Hal ini berarti secara simultan terdapat pengaruh yang signifikan dari variabel bebas terhadap variabel tidak bebas.

\section{Saran}

Adapun saran-saran yang dapat dipertimbangkan sehubungan dengan hasil penelitian adalah sebagai berikut :

1. Kebersihan toilet nilainya masih rendah oleh karena itu Anugerah Al-baghdadi Mebel Karawang perlu memperhatikan dan meningkatkan kualitas pelayanan dalam hal kebersihan toilet ini meliputi : dijadwal ualng kembali dan diperbanyak waktu lagi untuk pemeliharaan fasilitas pelayanan untuk konsumen, terutama dalam hal kebersihan dan kenyaman fasilitas fisik seperti kebersihan toilet yang ada di perusahaan.

2. Luas tempat parkir nilainya masih rendah oleh karena itu Anugerah Al-baghdadi Mebel Karawang perlu memperhatikan dan meningkatkan lokasi dalam hal luas tempat parkir ini meliputi : mencari alternatif lahan disebelah perusahaan atau lahan di daerah sekitar yang dekat dengan lokasi perusahaan untuk dijadikan area parkir bagi konsumen Anugerah Albaghdadi Mebel Karawang, sehingga persepsi kualitas pelayanan dalam hal luas tempat parkir akan lebih baik dimata konsumen.

3. Tersedia layanan customer service nilainya masih rendah oleh karena itu Anugerah Albaghdadi Mebel Karawang perlu memperhatikan dan meningkatkan wor dof mouth dalam hal tersedia layanan customer service ini meliputi : mulai membuat suatu sistem layanan customer service untuk para konsumen, agar perusahaan mampu melayani konsumen dengan lebih baik lagi. Minimal tersedianya layanan customer service di Anugerah Albaghdadi Mebel Karawang melalui layanan panggilan telepon.

4. Kesesuaian terhadap informasi produk nilainya masih rendah oleh karena itu Anugerah Al-baghdadi Mebel Karawang perlu memperhatikan dan meningkatkan keputusan pembelian dalam hal Kesesuaian terhadap informasi produk ini meliputi : Informasi tentang produk Anugerah Al-baghdadi Mebel Karawang yang dibuat atau disampaikan oleh karyawan dengan lebih jelas lagi, harus sesuai dengan kualitas produk yang sebenarnya. Selain itu, informasi produk harus lebih diperlebar lagi penyebarannya dengan menggunakan bauran promosi lainnya seperti periklanan dan publisitas. 
5. Karena mempunyai hubungan yang kuat, maka kualitas pelayanan dan lokasi harus tetap diperhatikan guna mendukung keputusan pembelian di Anugerah Al-baghdadi Mebel Karawang. Jika kualitas pelayanan meningkat maka lokasi juga akan meningkat. Sebaliknya jika lokasi meningkat maka kualitas pelayanan juga akan meningkat.

6. Karena mempunyai hubungan yang kuat, maka kualitas pelayanan dan word of mouth harus tetap diperhatikan guna mendukung keputusan pembelian di Anugerah Al-baghdadi Mebel Karawang. Jika kualitas pelayanan meningkat maka word of mouth juga akan meningkat. Sebaliknya jika word of mouth meningkat maka kualitas pelayanan juga akan meningkat.

7. Karena mempunyai hubungan yang kuat, maka lokasi dan word of mouth harus tetap diperhatikan guna mendukung keputusan pembelian di Anugerah Al-baghdadi Mebel Karawang. Jika lokasi meningkat maka word of mouth juga akan meningkat. Sebaliknya jika word of mouth meningkat maka lokasi juga akan meningkat.

8. Kualitas pelayanan secara umum berpengaruh terhadap keputusan pembelian namun kontribusinya lebih kecil dibandingkan dengan variabel Lokasi $\left(\mathrm{X}_{2}\right)$ dan Word of mouth $\left(\mathrm{X}_{3}\right)$ di Anugerah Al-baghdadi Mebel Karawang, sehingga perlu ditingkatkan kualitas pelayanannya dengan meningkatkan dengan selalu mengevaluasi setiap pelayanan yang diberikan kepada konsumen setiap bulannya, dan selalu memaksimalkan semua sumber daya yang dimiliki perusahaan termasuk karyawan untuk selalu memberikan pelayanan yang maksimal bagi konsumen Anugerah Al-baghdadi Mebel Karawang.

9. Meneliti aspek lain yang memiliki kemungkinan mempengaruhi keputusan pembelian, yang tidak dijadikan variabel dalam penelitian ini, karena berdasarkan hasil koefisien determinasi yang menunjukkan bahwa ada sebesar $17 \%$ variabel lain yang mempengaruhi keputusan pembelian, misalnya citra merek, atribut produk, kualitas produk dan harga..

\section{DAFTAR PUSTAKA}

Christina Widhya Utami. 2010. Manajemen Ritel, Edisi 2, Salemba Empat, Jakarta.

Daryanto, 2011. Sari Kuliah Manajemen Pemasaran, Bandung : PT Sarana Tutorial Nurani Sejahtera.

Dharmmaesta \& Irawan. 2010. Manajemen Pemasaran Modern, Edisi Kedua, Liberty, Yogyakarta.

Djaslim Saladin dan Herry Achmad Buchory (2010). Manajemen Pemasaran (Teori Aplikasi dan Tanya Jawab), Linda Karya, Bandung.

Fitzsimmons, James A and Mona J. Fitzsimmons. 1994. Service Management for Competitive Advantage. McGraw-Hill, Inc. New York.

Ghanimata, Fify Anita. 2012. Analisis Pengaruh Harga, Kualitas Produk dan Lokasi Terhadap Keputusan Pembelian pada Produk Bandeng Jwana Elrina Semarang. eprints.undip.ac.id 
Husein Umar. 2002. Metode Riset Bisnis, PT. Gramedia Pustaka Utama, Jakarta.

Husnul Khatimah, Asiah Hamzah dan Nurhayani. 2014. Pengaruh Bauran Pemasaran Terhadap Kualitas Pelayanan Pasien Di Instalasi Rawat Inap Rumah Sakit Ibnu Sina Makassar.http://repository.unhas.ac.id

J Schiffman, Leon dan Kanuk, Leslie Lazar, 2008, Perilaku Konsumen, Alih Bahasa : Zoelkifli Kasip, Edisi ketujuh, Indeks, Jakarta.

Kotler, Philip dan Gary Armstrong. 2012. Principles Of Marketing, 14th Edition, PrenticeHall Pearson, USA.

Kotler, Philip. dan Keller, K.L. 2007. Manajemen Pemasaran. Jilid I. Edisi ke 12. PT.Indeks. Jakarta.

Kotler, Philip. dan Keller, K.L. 2009. Manajemen Pemasaran. Jilid I. Edisi ke 13. Erlangga. Jakarta.

Kotler, Philip. dan Keller, K.L. 2012. Marketing Management, 14th Edition, Prentice Hall Pearson, USA.

M. Rizwar Ghazali dan Hidayati Retno. 2011. Analisis Pengaruh Lokasi, Promosi dan Kualitas Layanan Terhadap Keputusan Membeli (Warnet XYZ jl.singosari Semarang). Undergraduate Thesis, Fakultas Ekonomika dan Bisnis. eprints.undip.ac.id

Mimi SA. 2015. Pengaruh Harga, Kualitas Pelayanan, Lokasi dan Keberagaman Produk Terhadap Keputusan Pembelian Konsumen di Ranch Market. Jurnal Ekonomi/Volume XX, No. 01, Maret 2015 : 89-102

Mulyadi Nitisusantro, 2012, Perilaku Konsumen, Cetakan Pertama, Alfabeta, Bandung.

Nugroho, Marno dan Ratih Paramita. 2009. Analisis Pengaruh Lokasi, Keanekaragaman Barang Terhadap Keputusan Berbelanja Dan Loyalitas Konsumen di Carefour Semarang. Jurnal Ekonomi dan Bisnis, Januari, Vol 10. no 1.

Fadhila, Risa dan Sri, Rahayu Sri Astuti .2013. Analisis Pengaruh Word of mouth, Kualitas Layanan, Kualitas Produk dan Lokasi Terhadap Keputusan Pembelian Konsumen (Studi Pada Toko Leo Fashion Karangjati Kabupaten Semarang. Undergraduate Thesis, Fakultas Ekonomika dan Bisnis. eprints.undip.ac.id

Nur A'mirah Hassan Basri, Roslina Ahmad, Faiz. I Anuar, Khairul Azzam Ismail. 2016. Effect to Word of Mouth Communication on Consumer Purchase Decision : Malay Upscale Restaurant". Vol.222:324-332,doi:10.1016/jsbspro.2016

Ratih Hurriyati, 2010. Bauran Pemasaran Jasa dan Loyalitas Konsumen.

Ratna Dwi Kartika Sari dan Sri Rahayu Tri Astuti. 2012. Pengaruh Kualitas Produk, Harga dan Word of Mouth Communication Terhadap Keputusan Pembelian Mebel Pada CV. Mega Jaya Mebel Semarang, Diponegoro Journal of Management Volume 1, No.1.

Robbins, Stephen P. dan Coulter, Mary. 2010. Manajaemen (Edisi Kesepuluh). Erlangga, Jakarta.

Sarwono, Jonathan. 2012. Path Analysis dengan SPSS. Elex Media Komputindo. Indonesia.

Sekaran, U . 2006. Research Methods For Business, Edisi 4, Salemba Empat, Jakarta.

Sernovitz, Andy. 2012. Word of mouth Marketing. Kaplan Inc, New York.

Sudjana. 2002. Metoda Statistika. Edisi 6. Tarsito, Bandung.

Sugiyono. 2004. Statistika untuk Penelitian, Cetakan Keenam, CV. Alfabeta, Bandung.

Sugiyono. 2012. Metode Penelitian Kuantitatif, Kualitatif dan R \& D, CV. Alfabeta, Bandung.

Sugiyono. 2013. Metode Penelitian Kuantitatif, Kualitatif dan R \& D, CV. Alfabeta, Bandung.

Sugiyono. 2014. Metode Penelitian Pendidikan Pendekatan Kuantitatif, Kualitatif dan R \& D, CV. Alfabeta, Bandung. 
Suwatno dan Donny. 2014. Manajemen SDM dalam Organisasi Politik dan Bisnis, Alfabeta, Bandung.

Sutisna. 2001. Perilaku Konsumen dan Komunikasi Pemasaran, Remaja Rosdakarya, Bandung.

Tjiptono, Fandhy dan Chandra Gregorius. 2005. Manajemen Kualitas Jasa. Andi, Yogyakarta Tjiptono, Fandhy. 2007. Strategi Pemasaran, Edisi Kedua. Andi, Yogyakarta.

Wibowo . 2010. Manajemen Kinerja, Edisi Ketiga. Rajawali Pers, Jakarta.

Wijayanti, Irine Diana Sari, 2008. Manajemen, Mitra Cendikia Press, Yogyakarta.

Zeithaml, Valerie A. dan Mary Jo Bitner. 2008. Pemasaran Stratejik, Andi. Yogyakarta. 